\section{An Empirical Analysis of the Impact of Demutualization on Stock Exchange Performance: Lessons for Zimbabwe}

Davis Nyangara $^{1 *}$ and Tariro P Musikavanhu²

${ }^{1}$ Department of Finance, National University of Science and Technology, Bulawayo, Zimbabwe

${ }^{2}$ Securities Exchange Commission of Zimbabwe (SECZ), Harare, Zimbabwe

\begin{abstract}
This paper evaluates the impact of ownership structure on stock exchange performance using data from 50 stock exchanges for the period 1990 to 2011. The study adopts the Least Squares Dummy Variable (LSDV) regression model to examine the nature and significance of the relationship between stock exchange ownership structure and performance. The findings indicate that demutualized exchanges tend to perform better than mutual exchanges in terms of value of trades, market capitalization, and listings. Surprisingly, the study reveals that while combining demutualization and automation has a positive effect on market capitalization, automation is associated with reduced trading volumes and listings, ostensibly due to information efficiency effects of automation. While the general trend globally has been that automation precedes demutualization, Zimbabwe has plans to automate and demutualize its stock exchange around the same time. Given the clearly negative effect of automation on listings and volumes of trades, questions are raised regarding the efficacy of the model that Zimbabwe has adopted to boost domestic and foreign investor participation on its bourse. The study contributes immensely to the mounting evidence on demutualization, and the contemporary debate on the merits of demutualizing and automating the Zimbabwe Stock Exchange.
\end{abstract}

Keywords: Demutualization; Stock exchange

\section{Introduction}

The first stock exchange to demutualize was the Stockholm Stock Exchange in 1993, and since then, a number of stock exchanges around the world have been demutualizing. The changing landscape in the world's capital and financial markets arising from globalization has been cited as the reason for demutualization [1]. Schmiedel [2] reveals that due to recent technology improvements and changes in the competitive environment, new opportunities and threats have emerged and stock exchanges have responded by changing their ownership form. However, the pace of demutualization has been very slow in emerging markets as compared to developed economies. By 2005, about 21 exchanges in developed markets had demutualized representing almost $40 \%$ of the World Federation of Exchanges as compared to only 5 exchanges in emerging markets [3].

Mensah (2005) argued that the slow pace of demutualization in emerging markets such as Africa may be due to the fact that African governments are reluctant to undertake the process as long as they are satisfied with the performance of their mutual exchanges in terms of meeting their national objectives.

The Zimbabwe Stock Exchange is one of the oldest stock exchanges in Africa, having been formed in 1896 [4]. Although the ZSE Act was passed in 1974, to give legal form to the exchange and to govern the rights and obligations of members of the exchange, the exchange continues to operate as a mutual entity governed by its members (brokers). The Securities Commission of Zimbabwe (SECZ), which was established in 2008, to oversee the regulation of capital markets, has been calling for various reforms to the ZSE, which include demutualization. The issue has been met with mixed feelings among capital market players with some resisting the idea altogether. Most stockbrokers have however resisted demutualization on the basis that it is just but a change in ownership structure, with no notable potential benefits (Financial Gazette 19/11/2010; ZBC Online 14/07/ 2011, 1751 hrs.). This debate has stalled much progress on demutualization and it is apparent that econometricmodeling has an important place in this debate. What the parties to this debate need is hard statistical evidence that confirms the relationship between ownership status and performance.

The contribution of this paper is in four ways. Firstly, it generates hard statistical evidence on the relationship between ownership status and stock exchange performance. Secondly, it extensively reviews the literature on drivers of stock exchange performance. Thirdly, on the basis of the extant literature, it highlights the implementation 'red flags' that parties need to resolve to ensure a successful demutualization. Lastly, it raises questions on the wisdom of implementing both demutualization and automation at the same time.

The rest of the paper is organized as follows: Section 2 provides an extensive review of the literature on demutualization; Section 3 outlines the methodology of the study; Section 4 presents the findings; and Section 5 concludes the study.

\section{Literature Review}

Stock exchanges all over the world initiate demutualization hoping to empower the market and to increase revenues. However, the trend of stock exchange demutualization continues to generate debate amongst academics and policy makers on the impact of such conversion; from mutual to demutualized organizational form. There remains a school of thought Lee, Kongden and Shleifer and Vishny [5-7] that is against demutualization. A question is often raised of whether demutualization has so far succeeded or not. Of particular importance is the impact

*Corresponding author: Davis Nyangara, Department of Finance, National University of Science and Technology, Bulawayo, Zimbabwe, Tel: 263773494558 ; E-mail: dvsnyangara@gmail.com

Received January 29, 2014; Accepted February 01, 2014; Published February 10,2014

Citation: Nyangara D, Musikavanhu TP (2014) An Empirical Analysis of the Impact of Demutualization on Stock Exchange Performance: Lessons for Zimbabwe. Int J Econ Manag Sci 3: 161. doi: 10.4172/2162-6359.1000161

Copyright: (c) 2014 Nyangara D, et al. This is an open-access article distributed under the terms of the Creative Commons Attribution License, which permits unrestricted use, distribution, and reproduction in any medium, provided the original author and source are credited. 
of demutualization on the stock exchange itself (as an organization) as it eventually extends the impact on other stakeholders (investors, employees, government, etc.).

While Aggarwal [1] Mendiola and O’Hara [8], Aggarwal and Dhahiya [9] found positive effects of demutualization on stock exchange performance. Hart and Moore [10] argued that outside ownership and member co-operatives are both inefficient forms of governance structures as outside ownership is mostly interested in short time gains while collective decision making in cooperatives make stock exchanges inefficient. Lee [5] states that demutualization is neither necessary nor sufficient for the prosperity of stock exchanges. Cybo-Ottone et al. [11] saw demutualization as a necessary condition to change current shareholders and management.

Steil [12] added an interesting dimension to the discussion as he argued that the change in governance structure of an exchange is not important as demutualized exchanges can still provide the same services and accrue the same benefits as in mutual exchanges. Kongden (1998) also found that mutual exchanges are able to maximize the interests of both parties concerned as opposed to demutualized entities.

\section{Stock exchange ownership structures}

In the academic world there are different and continuous discussions about the forms of stock exchange ownership structures. Di Noia [13] asserts that stock exchanges have various ownership structures as he classified them as either public entities, cooperatives of intermediaries or corporations controlled by intermediaries, institutional investors, issuers, and outside owners. On the other hand, Pirrong [14] classified stock exchanges as either for-profit or non- profit mutual entities. Pirrong [14] argued that the organizational structure of stock exchanges is as a result of trading rules governing the trading process. In his analysis Pirrong [14] affirmed that if an exchange can charge a super marginal cost for its services and distribute profits to its members then the exchange is classified as a for-profit stock exchange either as a corporation, partnership, or a for- profit co-operative or mutual. In cases where the exchange sets the price for its services equal to the marginal cost and forms a cartel among its members and limits the number of members, then the exchange is a non-mutual exchange.

Unlike Pirrong [14] Hart and Moore [10] classified stock exchanges as either member cooperatives or outside-owned exchanges depending on who had the residual claim or control over non-human assets. In case of member co-operatives, members control the exchange and in outside ownership, control rests with outside owners who are only interested in profit maximization.

The general consensus among the above researchers is the fact that traditionally, stock exchanges were organized as mutual associations and under this governance structure, the exchanges were owned by members. Ownership and right to consume the services were bundled together, Hart and Moore [10], Di Noia [13], Aggarwal [1], Steil [12]. In a mutually owned exchange, according to Aggarwal [1] members enjoyed the rights of ownership, decision making (one-member, onevote), and trading and as a result, members controlled the price, quality and range of services produced by the exchange.

According to Hart and Moore [10], Domowitz and Steill [15] the mutual structure was a remnant of an era before system automation as trading required visual and verbal interaction. As such, exchanges where physical location where traders would meet at designated places to transact business. Trade was conducted in person and multiple securities were traded at the same location to maximize liquidity,
Hazarika [16]. For centuries, the exchanges (such as the Amsterdam which was established in 1600, LSE in 1760, and NYSE which traces its roots to 1792 among others) were able to maintain the mutual ownership structure as a result of the monopoly power that was inherent in members of the exchange, Pirrong [14].

As the operating environment began to change and competition took center stage, the majority of exchanges started to change their organizational and operational structure. Hazarika [16] argued that members of mutual exchanges failed, due to the structure of the exchange, to vote to bring in policies to improve efficiency and to act and react to changes. To overcome this, exchanges were therefore forced to demutualize.

\section{Models of exchange governance choice}

The most popular models though they yielded different results in stock exchange governance structure analysis were that of Hart and Moore [10], Pirrong [14] Hart and Moore [10] analyzed the efficiency of an exchange run as members' cooperative relative to that of a forprofit exchange with outside owners. Hart and Moore [10] concluded that a member cooperative is said to be more efficient if members are homogeneous and as the skewness of member size distribution is increased, outside ownership structure becomes more efficient. Contrastingly Pirrong [14] based his analysis on the impact of member heterogeneity and concluded that more heterogeneity favors a not-for profit exchange which he likened to members' cooperative.

The outcomes of Hart and Moore [10], Pirrong's [14] models were completely different. To start with, the authors defined governance choice differently. According to Hart and Moore, a member's cooperative structure is where profits are distributed to members equally and members face a tradeoff between the desire for cheap trading and the desire for profits, whereas Pirrong's version allows no profit distribution. Hart and Moore's version of a profit exchange is one that separates ownership from membership entirely whereas Pirrong does not separate them at all. Moreover the source of member heterogeneity is different in the models. Pirrong assumes that they differ only on efficiency dimension i.e. there are higher and lower cost brokerage services providers whereas Hart and Moore assume that members differ only in the quantity of exchange services they demand.

Both models however failed to explain the drivers of the actual trend towards demutualization. Pirrong's model does not capture the possibility of an exchange with outside ownership which is an important feature of demutualization i.e. separation of ownership of an exchange from its members. Hart and Moore's model illustrates that member-owners want both low exchange costs and high profits and outside owners are interested in high profits. This incentive structure can have a significant impact on exchange policies.

Furthermore, Hart and Moore rely on the assumption that exchange policies are put in place based on the majority voting of the members which is impossible in an environment where competing trading venues can and do exist, [13]. Large members will have greater influence because of their ability to migrate their trading activity. Lastly, both Pirrong and Hart and Moore failed to take into account the casual relationship between trading technology and exchange governance. It is a fact that all manual exchanges logically began as cooperatives and only revisited their governance structures after trading automation making demutualization a viable option. 


\section{Demutualization of stock exchanges}

Demutualized exchanges can be classified into two types depending on whether they are listed or non-listed. An exchange can therefore be demutualized and become a public company listed on its own exchange or demutualized but remain a private company $[1,17]$. Other demutualized exchanges are subsidiaries of holding companies, Morsy and Rwegasira [18]. Empirical evidence includes the Australian Stock exchange, Singapore Stock exchange, and Johannesburg Stock exchange, which are public companies listed on their own exchanges. The Toronto Stock exchange and the Amsterdam Stock Exchange are still private corporations while OM Stockholm is a wholly owned subsidiary of a listed company [19].

Shahid [20] defined demutualization as the conversion of stock exchanges from a mutually owned organization to a company owned by various entities including the public. Emphasis on demutualization is on the separation of ownership and membership and not necessarily on profit as generally perceived in informal discussions. Many stock exchanges can legally distribute profits to its owners, even if they are not demutualized [12]. What is essential to successful demutualization is to have non-members free to buy equity stakes in the exchange from current owners [12]

Numerous reasons have been put forward to explain this change in organizational structure of stock exchanges from mutual to demutualized entities. According to Aggarwal [1], Schmiedel [2] the changes were driven by increased global competition, technology and the growing conflict of interest between existing owners. Steil [12] further pointed out that demutualization was triggered by the effects of competition and the dilution of national membership.

Ramos [21] also ascertained that demutualized entities then go public in order to raise new capital and finance acquisitions. However, empirically this view is disputed as it is found that most exchanges such as the Amsterdam Stock Exchange that demutualized had no immediate need for fresh capital but actually used its demutualization as an opportunity to return excess capital to its members [12]. According to this view, raising capital is not necessarily the main aim of demutualization as capital can simply be raised from member firms without having to demutualize. The primary reason for demutualization is thus the need to reduce the control of local intermediaries over the strategic positioning of the exchangen [12]

\section{Impact of demutualization on stock exchange performance}

Although authors such as Aggarwal [1], Morsy and Rwegasira [18] support demutualization and self-listing of stock exchanges by emphasizing the advantages of the process, opponents of demutualization do not believe that the process may bring the expected benefits to the capital markets. They argue that the benefits of demutualization can also be obtained with a mutual governance structure and they point out that forming a new financial institution is very hard considering the fragility of the investor confidence to the financial system especially in the context of emerging markets [5,7].

Proponents of demutualization such as Mendiola and O'Hara [8] presented evidence that shifting corporate governance from a cooperative to a demutualized structure enhances value for exchanges. They found that demutualized and self-listed stock exchanges generally outperformed both the stocks on their markets and the IPOs listed on these exchanges. The study however concentrated on publicly listed exchanges and provided no comparison to mutual exchanges.
Domowitz and Steil [15] posit that members of mutualized stock exchanges have incentives to oppose innovations even when such innovations increase exchange value, and thus demutualized stock exchanges should result in a better market quality compared to mutualized ones. Krishnamurti et al. [22] test this implication using two major Indian stock exchanges, the Bombay Stock Exchange (BSE) and the National Stock Exchange (NSE), which were mutualized and demutualized, respectively. They demonstrated that NSE provided a better market quality than BSE and thus concluded that demutualization improves stock exchange performance.

Hazarika [16] analyzed two demutualized stock exchanges, the London Stock Exchange and the Borsa Italiana, and found out that demutualization helped both exchanges to increase their trading volumes. Aggarwal and Dahiya [9] reported that conversion to forprofit status and public ownership has significantly increased both operating performance and share values. Using the Australian Stock Exchange (ASX) as a case study, Otchere and Abou-Zied [23] showed that the profitability ratios of the ASX, and the market quality, using both trading activity by foreign investors and bid-ask spreads as proxies for market quality, improved following ASX's demutualization and self-listing.

$\mathrm{Nu} \mathrm{Ri}$ [24] also favored demutualization as he argued that demutualization opens up various opportunities for exchanges which include merging/ consolidation among stock exchanges not only within the area they operate in but also across the borders in order to become more competitive, for example, Paris, Brussels, Amsterdam, Lisbon and LIFFE stock exchanges have combined to form Euronext Group and Euronext merged with NYSE [24]. The consolidation of stock exchanges enables them to devise new ways and strategies to make them more competitive hence impacting positively on stock exchange performance.

Despite the majority of the above mentioned authors agreeing on the positive impact of demutualization on stock exchange performance, Lee [5] argued otherwise. In his analysis, he showed that the benefits derived from demutualized exchanges with direct investor access were actually low as compared to the benefits that can be obtained from the presence of brokers with ownership interest in the exchange. Steil [12], Lucy [25] focused on the conflict of interest inherent in demutualized exchanges. They argued that the emergence of the demutualized forprofit stock exchange aggravates the conflicts of interest related to running the stock exchange as a commercialized entity and as a selfregulatoryorganization (SRO). If this conflict of interest is not properly managed then, demutualized exchanges will seek profit maximization and according to Lee [5], will behave the same way as monopolistic enterprises; raise price and reduce output which will have a negative impact on stock exchange performance.

On a different note, Otchere and Oldford [26] argued that the improvement in performance of demutualized and listed stock exchanges may be attributed to changes in the stock exchanges' business models (the adoption of a for-profit objective function) or to the effects of market discipline not necessarily the change in ownership structure. In that case, demutualization has no effect on stock exchange performance. Kongden [6], Macey and O'Hara [27] also argued in favor of a mutual structure as they concluded that it is only with a mutual structure is it possible to maximize the interests of both parties when planning relationship-specific investments between the exchange and its users. The operation consists of a mutual investment where the shares are provided by the customers and the services by the bourse. 
However, in case of the structure not being a co-operative, each party could exploit the other, since they will be having nondiversifiable investments in the relationship [27]. Due to the possibility of exploitation, each party would want to manage the exchange and, consequently, the best structure to reach the interests of both parties would inevitably be the co-operative form. Pirrong [14] argued that, in the absence of a mutual structure, specialized human and reputational capital would be vulnerable to expropriation by outside owners. Under these circumstances, trader ownership of exchange assets economizes transaction costs and since rules affect trader wealth, governance by members limits the scope for wasteful opportunism. In this case, Pirrong [14] argued in favor of a mutual structure as opposed to a demutualized structure.

\section{Critical issues in demutualization}

Although demutualization of stock exchanges is believed to bring various benefits to the exchanges, the opponents argue that demutualization will bring lots of problems which include the determination of the owners of the demutualized exchange and the sources of income and the targeted services, forming the management of the exchange, developing convenient listing and disclosure standards and forming appropriate audit and supervision commissions. In addition, developing a fair system that will constitute and strengthen the confidence of investors is considered as one of the biggest problems. Issues such as conflict of interest, regulatory and legislative issues among others need to be addressed if demutualization is to be successful $[28,29]$.

Conflict of interest: Mixed findings relating to the scope and intensity of conflict of interest issues have been found in literature. While Steil [12] argued that the scope for conflict of interest is less in demutualized entities than in mutualized entities, authors such as Coffee [28], Karmel [29] argued otherwise. Steil [12] argued that conflict of interest issues are rampant in mutual exchanges as these exchanges are established only to serve the interests of members. If they fail to do so effectively they will be reformed or disbanded and as such demutualized entities have less incentive to support the interest of members than do member-owned exchanges.

Contrarily, Coffee [28], Karmel [29] argued that the emergence of demutualized for-profit stock exchanges aggravate the conflict of interest related to running a stock exchange as a commercialized entity and as a regulatory entity. The authors affirmed that the main target of a demutualized for-profit exchange will be to achieve profits instead of allocating adequate resources to enhance regulation of the market and its participants. Thus a demutualized exchange increases the scope of conflict of interest as revenues generated by the exchange must meet expenses and additionally generate a rate of return for shareholders thereby foregoing adequate allocation of resources towards enforcement of rules and regulations [19]. However, in disagreement with this argument are Hughes and Zargar (2006), whosubmit that demutualized stock exchanges will infact establish rigorous standards in order to be distinguished with the services they provide. In a survey of companies listed on the New York Stock Exchange (NYSE), Hughes and Zargar found that companies seek a listing on the NYSE partly because of the reputational capital that comes as a result of being listed on one of the world's leading stock exchanges (Hughes \& Zargar 2006).

On the other hand, Akhtar (2002) asserted that, the degree of conflict at the exchange level exists whether an exchange has a mutual or a demutualized structure, though the nature of the conflicts and responses to addressing these conflicts may differ depending on the type of exchange and the range of businesses it ventures in. In the mutual exchange, the key challenge is how to balance the members' (who are owners) interest with that of the public, whereas a demutualized exchange has to balance its commercial objectives and regulatory objectives.

For Hughes and Zargar (2006), this potential conflict of interest is minimized with the existence of a government regulator that provides oversight over the regulation of the stock exchange and by restriction on ownership. In line with Hughes and Zargar's arguments, ASIC has been made responsible for administering listing rules in the case of the ASX. When the London Stock Exchange decided to change its ownership structure in June 1999, its regulatory role of the primary market was transferred to the Financial Services Authority. The Monetary Authority of Singapore is authorized through a Memorandum of Understanding to monitor compliance with listing requirements of the Singapore Exchange [19].

Regulatory issues: Demutualization of stock exchanges has witnessed a shift in regulatory landscape of most exchanges [9]. Historically stock exchanges have been operating in most countries as self-regulatory organizations (SROs). In this role, stock exchanges have set listing standards for companies that list and trade on the exchange and have set rules for trading [18].

Demutualization has paved way for exchanges to list on their exchanges which give rise to conflict of interest issues. The conflict is evident not only in satisfying listing requirements continuously but there could be conflicts in the corporate objectives of the exchange and its regulatory role, conflict with other competing companies that are also listed on the exchange, (IMF 2002). A classic case was the bid made by the self-listed Australian Stock Exchange (ASX) for the shares of the Sydney Futures Exchange. A counter bid by Computershare Ltd, another listed company, cast doubts about the obligation of the exchange to enforce listing rules [18].

Aggarwal [1] also argued that a demutualized exchange can still continue to carry out its regulatory function that it used to perform pre-demutualization. The exchange may only need to appoint public interest directors to represent the public beyond the owners. These directors will be expected to serve as a check on conflict of interest issues in an SRO and promote integrity in the board's decision making [19].

Legal issues: The process of demutualization has taken various forms among exchanges and a number of legal issues need to be considered. In certain jurisdictions, the exchange is a company limited by guarantee, and in this situation, the demutualization process entails converting membership into shares. In other jurisdictions, the exchange could be a mutual entity limited by shares, where the liability of members is limited to any amount which is unpaid on the shares in the company. In other instances, the exchange could be a state-owned corporation requiring privatization rather than demutualization [19]. In all the above scenarios, there is need to amend the existing legislation or to enact a separate piece of legislation to enable the stock exchanges to convert their structures, (IMF 2002).

Empirical examples include the case in Malaysia, where demutualization was effected under a specific legislation, the Demutualization (Kuala Lumpur Stock Exchange) Act while relevant amendments were made to the existing legislation governing the securities and futures industries. In South Africa, a new legislation was promulgated to provide for the ability of the domestic exchanges to demutualize. In Indonesia, amendments to the Capital Market 
Law were done.In Australia, the Corporations Law (the governing legislation for corporations, and securities and futures markets) had to be amended to enable ASX to become a for-profit company and contemporaneously list on its own exchange [19]. However, according to Morsy and Rwegasira [18] enactment or amendment of legislation involves a fairly long process which may hinder the timely demutualization of exchanges.

Control over stock exchanges has also been an issue that has been debated in literature. According to the IMF (2002), no-one should control the exchange and as such, there should be a restriction on the size of shareholding. For example under the UK Law, ownership in the LSE is limited to $10 \%$ and similarly the Swedish Law states that any one person can own only $10 \%$ of an exchange unless an exemption is granted. ASX is $15 \%$. Limit on shareholding is imposed to prevent concentration of holding and the consequent transfer of control, (Morsy 2008). However, given that demutualization is aimed at allowing the exchange to operate in its own right rather than an extension of its members or users (Seagal 2001), continuing to restrict ownership to such small amount (e.g. 5\% in the case of Toronto Stock Exchange) may defeat the whole purpose of demutualization. Some exchanges have gone to the extent of restricting by type of owners, (IMF 2002). If the exchange is seen as a national public good, the law may prohibit foreign ownership and ownership could also be limited to those with some expertise in its operation.

\section{Key drivers of stock exchange performance}

Stock Exchange ownership structure, technological advancements especially the adoption of automated trading systems, level of economic development as well as the age of an exchange were found to have an impact on stock exchange performance as highlighted in studies documented below.

Ownership structure: The theoretical framework on the effect of ownership structure on stock exchange performance is founded on the Agency theory by Jensen and Meckling [30] By demutualizing exchanges, outside owners (shareholders) are given ownership stake in the exchanges and like any other firm will appoint a board that would delegate the day to day running of the organization to managers (agents). The agency problem arises due to the separation of ownership and control of the exchange where the principals (shareholders) and managers (agents) have conflicting ideas on how the exchange should be run. In cases where ownership is highly concentrated in outside shareholders, researchers found conflicting results and arguments.

Aggarwal and Knoeber [31] found positive effects of high concentration as they argued that large shareholders have both the ability and incentive to monitor and control agents in order to operate the firm to the good of the shareholders i.e. incentive alignment. The costs of monitoring by large shareholders thus yield better performance of the firm. By shifting the ownership of the exchange from members to a wider group of investors with adequate safeguards, and by appointment of a professional board, management will be forced to operate efficiently, transparently as they will be held accountable [31]. Thus demutualization should have a positive impact on stock exchange performance.

Other studies, however, found negative effects and argued that increased control by large shareholders in firms reduces self-realization of managers who consequently get discouraged i.e. over monitoring (Burkart et al. [32]; Pagano and Roeill [33] Fama and Jensen [34] argued that the higher the ownership concentration, the lower the liquidity of stocks because there will be less shares available for trade on the market. As a consequence, the stocks become more risky as the beta of the firms increase and the cost of capital gets driven up thereby impacting negatively on firm performance. Otchere [17] however postulates that demutualized exchanges should have restriction on ownership structure to mitigate concentrated ownership that would potentially destroy the benefits of good governance. He went on to say that controlling shareholders and owners may not act in the best interest of the minority shareholders unless such ownership restrictions are placed.

Some studies however, found no observable effect of ownership concentration on corporate performance. Becker (1962) put forward the natural selection argument which states that corporations perform equally well under different ownership structures because market competition will eliminate all inefficient forms in the long run and as such ownership structure will not have any effect on firm performance. According to Kole and Lehn [35] corporate performance depends on environmental constraints; it has nothing to do with the ownership structure.

Trading technology: Researches done on the impact of automated trading systems on stock exchange performance have produced conflicting results. Benveniste et al. [36], Biais et al. [37] have shown that automation has a negative impact on stock exchange performance as it leads to a decrease in liquidity. They argued that in a manual system, floor traders share information on the characteristics of trade and intrinsic value, allow for direct negotiations between traders for important transactions thereby reducing information asymmetry and increasing liquidity as compared to automated trading.

Conversely, Pirrong [14] argued that automation has a positive impact on stock exchange performance as automated stock exchanges are deeper and more liquid than open outcry exchanges. Naidu and Rozeff [38] noted an increase in volatility and liquidity as well as an improvement in efficiency following the automation of Singapore Stock Exchange. Macey and O'Hara [27] looked at the impact of automation on price discovery and market efficiency and concluded that automation enhances price discovery or how efficiently new information is incorporated into price. They emphasized that more efficient price discovery contributes to better informed financing and investment decisions, benefiting shareholders by facilitating better corporate decisions, hence impacting positively on stock market performance.

Galper [39], Cybo-Ottone et al. [11] revealed that automation fundamentally altered the financial market landscape, enabling exchanges to overcome location differences as the trading system could be accessed from different locations thereby increasing the number of users. Increase in the number of users ultimately increased investor participation, hence making markets more liquid impacting positively on stock market performance. Sebet and Otchere [17] conducted a survey of African stock exchanges and found out that automated exchanges had better turnover indictors than manual exchanges. The authors concluded that automation reduces costs and inefficiencies associated with manual systems and increase trading activity and liquidity in the stock market.

Level of economic development: The nature of the relationship between economic development and stock market performance remains debatable despite a wealth of previous research in this area. The direction of the causality is not clear i.e. whether stock market development causes economic development or itself is a consequence 
of increased economic activity. Literature review confirms that four different scenarios about the nature of the relationship can be obtainable.

The first scenario is the demand-following hypothesis put forward by Patric [40] which states that stock market development follows economic development. As the economy improves, stock market performance should also improve. Authors such as, Ibrahim [41] Charkavarty [42] noted that as the economy expands, demand for certain financial instruments increases and increased macroeconomic activity influences stock market performance positively. Levine and Zervos [43] were in agreement with this view as they argued that economic development makes the development of financial intermediaries system profitable, and the establishment of an efficient financial system permits faster growth. Thus developed markets should have developed stock markets.

Contrarily, the second scenario confirms a uni-directional causality running from stock market development to economic growth commonly referred to as the supply leading hypothesis, Patrick [39] Bencuvenga, Smith [44], N'zue [45] contend that a well-functioning stock market channels limited resources from surplus units to deficit units and in so doing provide an efficient allocation of resources, thereby resulting in economic growth. Tuncer and Alovsat [46] also supported this view that stock market development promote economic development not the other way round and acknowledged that stock markets, due to their liquidity, enable firms to attain much needed capital quickly, hence facilitating capital allocation, investment and growth hence leading to economic growth. The implication of this argument is that the level of economic development does not affect stock market performance but it is in fact the stock market performance that has an impact on the level of economic development.

Besides a one way relationship (stock market development leading to economic development or vice versa) the third scenario looks at a bi-directional causality effect between the two. Authors such as Luintel and Khan [47] Garcia and Lui [48] assert that a two way relationship exists between the level of economic development and stock market performance i.e. bi- directional casualty effect. They argued that an economy with a well-developed stock market promotes high economic expansion through technological changes, products and services innovation. This will in turn create a high demand for the stock market products. As the stock market effectively responds to this demand, these changes will stimulate higher economic growth. Both financial and economic developments are therefore positively interdependent and their relationship could lead to bi-directional causality. In this scenario, improvement in the level of economic development leads to improved stock market performance and vice versa.

The final view is what is referred to as the independent hypothesis which argues that stock market growth and economic growth are not causally related implying that there is no relationship between the two variables i.e. economic development and stock exchange performance $[49,50]$. Clearly the literature on the causal relationship between the stock market development and economic growth is inconclusive. In reviewing the literature one cannot help but suspect that the different views exist in part because of the differing methodologies used, in particular cross sectional versus time series studies, and also due to the evolving techniques used.

Age of stock exchange: In the finance literature, the relevance of age to firm dynamics in general has attracted comparatively little attention. The study hence can only mention a few inconclusive studies that were done relating to firms in general. According to Arrow (1962) and Erison and Pekas (1995), age has a positive impact on firm performance. They argued that over time, firms discover what they are good at and learn to be more efficient and as such they find ways to standardize, coordinate, and speed up their production and processes as well as to reduce costs and improve quality thus having a positive impact on firm performance. On the other hand, Leonard-Barton [51], Hannan and Freeman [52] argued that age has adverse effects on firm performance because of organizational rigidity and inertia it bring about. They also asserted that age in fact makes knowledge, abilities and skills obsolete thus leading to organizational decay.

The arguments put forward by the above authors cannot however be relied upon to conclude the effect of age on stock exchange performance. Mendiola and O'Hara [8], Otchere [17] found that listed stock exchanges, such as ASX, Deutsche Borse, Singapore Exchange and Toronto Stock Exchange, generally outperformed the stocks listed in their markets and other listed Initial Public Offerings (IPOs). By analyzing the age of these exchanges, it can be noted that these exchanges were established in different periods yet they all performed well, meaning that age had no effect on the performance of these exchanges.

Moreover by looking at the top performing exchanges in the world in 2011, WFE [3], which included NYSE, LSE, ASX, Hong Kong and Deutshe Borse among others, it can be deduced that despite these exchanges having different ages, they performed better in terms of market capitalization and revenue generated in 2011. Thus in essence, the question remains whether the performance of an exchange has nothing to do with its age or whether aging helps stock exchanges prosper or whether it dooms them.

The literature has shown that stock exchanges have an option to remain mutual or to demutualize and demutualized stock exchanges can also go a step further and list on their own exchanges. Despite the benefits derived from demutualization, demutualization itself is not without risk as there are a lot of issues (e.g. legal, regulatory and conflict of interest) that need to be addressed pre and post demutualization.

\section{Methodology}

This study was guided by the positivist paradigm, relying heavily on empirical analysis using econometric techniques and hypothesis testing. The following sections provide a brief outline of the approach to gathering essential evidence for the study.

\section{Specification of data used}

Secondary data on stock exchange performancewas collected from sample exchanges' websites, survey reports of the World Federation of Exchanges as well as the IMF and World Bank databases. The study used panel data which covered the period 1990- 2011 for each of 50 stock exchanges. Panel data is very useful as it takes into account the heterogeneity of stock exchanges. Moreover by combining time series and cross sectional observations, panel data gives more informative data, more variability, less collinearity among variables, more degrees of freedom, and more efficiency. Since all exchanges had the same number of time series observations from 1990-2011, the study made use of a balanced panel.

However, the use of panel data has its own drawbacks. Panel data can pose estimation and inference problems. Since such data involve both cross-sectional and time series dimensions, problems that plague cross-sectional data (e.g. heteroscedasticity) and time series data 
(e.g. autocorrelation) need to be addressed and in some cases there can exist cross correlation in individual units at the same point in time. Moreover, if many variables are considered, there is always the possibility of multicollinearity, which might make precise estimation of one or more parameters difficult.

\section{Research variables used}

To determine the level of stock market development for each exchange, the following market indicators were used as discussed by Yartey (2008): Market capitalization ratio, value of stock traded as a \% of GDP and number of listed companies. Market capitalization ratio and the number of listed companies are used to measure the size of the stock market. The market capitalization ratio is defined as the value of domestic equities traded on the stock exchange relative to GDP. On the other hand, the activity of the stock market which is measured by the total value traded as a share of GDP is used to gauge market liquidity [43]. Liquidity is the ease and speed at which economic agents buy and sell shares. The more liquid the stock market, the larger the amount of savings that are channeled through the stock market, hence a more liquid market should lead to high stock market development [53]. Thus the value of stock traded relative to GDP is used to measure the degree of trading relative to the size of the economy and is a good indicator of the population's propensity to invest.

\section{Data analysis}

The study used the LSDV model to find out how stock exchange performance $(\mathrm{Y})$ depends on the following independent variables: age, demutualization Status of the Exchange (DS), Time Since Demutualization (TSD), Economic Status (ES), Automation Status (AS), Time Since Automation (TSA). The econometric model used is specified below:

$$
\mathrm{Y}=\beta_{0}+\beta_{1} \text { Age }+\beta_{2} \mathrm{DS}+\beta_{3} \mathrm{TSD}+\beta_{4} \mathrm{ES}+\beta_{5} \mathrm{AS}+\beta_{6} \mathrm{TSA}+\mu_{\mathrm{i}}
$$

Since performance indicators of stock exchange include market capitalization ratio, value of stock traded and number of listed companies, the dependent variables were each in turn regressed against all the independent variables.

The LSDV Model was used as it takes into account the unique features of each exchange such as management style or talent as a common intercept is not imposed on all the exchanges. To adjust the intercept, three dummy variables were used and were classified as either mutual or demutualized, either manual or automated, and either from developed or less developed economies. The dummy variables were constructed such that they take values of 1 for demutualized, automated, or developed statuses; otherwise they took a value of zero. The cross-sectional differences were therefore captured by DS, AS and ES.

A correlation matrix was constructed for the explanatory variables to test for multicollinearity, where if the correlation coefficient between any two independent variables is $>.80$, one of the variables is dropped to avoid the problem of multicollinearity in the regression. However, in this study multicollinearity was found not to be a problem.

\section{Findings}

\section{Multicollinearity test results}

The correlation matrix in Table 1 shows that the strongest positive relationship exists between DS and TSD, where $r=$ increases as each year passes by and the same reasoning can be applied to AS and TSA, which also shows a strong and positive relation of 0.74 . Economic status (ES) is positively correlated with age (0.49), demutualization (0.36), and Automation (0.29), with developed economies likely to have older, demutualized, and automated exchanges.Demutualization and automation of stock exchanges work hand and in hand, with demutualized exchanges likely to be automated. This is evidenced by a strong positive relationship of 0.66 between TSD and TSA and of 0.62 between DS and TSA. Based on the correlation matrix, multicollinearity was deemed not to be a problem in the data.

\section{LSDV regression output}

This is because as an exchange is demutualized, the number of years it will operate as a demutualized exchange

Market capitalization: As shown in Table 2, DS, ES, and TAS have a significant positive impact on market capitalization, while Age and TSD havea significant negativeimpact on market capitalization. The automation status (AS) of an exchange is observed to have a positive but insignificant impact on market capitalization. It is interesting to note that while the demutualization status of an exchange has a significant positive effect on market capitalization, time since demutualizationhas a significant negative effect on market capitalization. This result is however not very surprising in view of the significant erosion of stock values on developed exchanges (which are the bulk of demutualized exchanges) during the recent global financial crisis that started around 2007

Value of stocks traded: Table 3 shows that although all the independent variables with the exception of AS have a positive impact on the value of stocks traded, the impact is more pronounced for demutualizationstatus and economic status. Thus, demutualized stock exchanges in developed economies record the most trading activity. Age has a positive but insignificant impact on value of stocks traded as shown by a p-value of 0.2757 . Surprisingly, automated exchanges exhibit less trading activity than non-automated exchanges after controlling for other factors. However, the model shows that automation impacts trading activity positively over time, as shown by a significant positive partial regression coefficient for TSA. Overall, only demutualization status, economic status, and time since automation have statistically significant positive effects on trading activity.

Number of listings: From Table 4, it can be observed that DS, ES, TSA, and AGE have significant positive effects on stock exchange listings. Automation status (AS) and time since demutualization (TSD) have significant negative effects on stock exchange listings.

\begin{tabular}{|c|c|c|c|c|c|}
\hline & AGE & DS & TSD & ES & 0.49 \\
\hline AGE & 1.00 & 0.35 & 0.31 & 0.36 & 0.33 \\
\hline DS & 0.35 & 1.00 & 0.82 & 0.35 & 0.44 \\
\hline TSD & 0.31 & 0.82 & 1.00 & 0.32 & 0.00 \\
\hline ES & 0.49 & 0.36 & 0.35 & 0.29 & 0.29 \\
\hline AS & 0.33 & 0.44 & 0.38 & 0.32 & 0.00 \\
\hline TSA & 0.32 & 0.62 & 0.66 & 0.74 & 0.00 \\
\hline
\end{tabular}

Table 1: Correlation Matrix. 
Citation: Nyangara D, Musikavanhu TP (2014) An Empirical Analysis of the Impact of Demutualization on Stock Exchange Performance: Lessons for Zimbabwe. Int J Econ Manag Sci 3: 161. doi: 10.4172/2162-6359.1000161

Page 8 of 10

\begin{tabular}{|c|c|c|c|c|c|c|c|c|}
\hline \multicolumn{2}{|c|}{ Regression Output } & & & & & & & \\
\hline Multiple R & 0.43 & & & & & & & \\
\hline R square & 0.19 & & & & & & & \\
\hline $\begin{array}{l}\text { Adjusted } R \\
\text { square }\end{array}$ & 0.18 & & & & & & & \\
\hline Standard Error & 63.19 & & & & & & & \\
\hline Observations & 1100 & & & & & & & \\
\hline \multicolumn{9}{|l|}{ ANOVA } \\
\hline & $d f$ & SS & $M S$ & $F$ & Significance $F$ & & & \\
\hline Regression & 6 & 991,404 & 165,234 & 41.38 & 0.00 & & & \\
\hline Residual & 1093 & $4,364,268$ & 3,993 & & & & & \\
\hline \multirow[t]{2}{*}{ Total } & 1099 & $5,355,671$ & & & & & & \\
\hline & Coefficients & Standard Error & $t$ stat & $P$-value & Lower 95\% & Upper & Lower $95.0 \%$ & Upper $945.0 \%$ \\
\hline Intercept & 31.9370 & 3.2156 & 9.9318 & 0.0000 & 25.6275 & 38.2466 & 25.6275 & 38.2466 \\
\hline AGE & -0.1064 & 0.0271 & -3.9192 & 0.0001 & -0.1597 & -0.0531 & -0.1597 & -0.0531 \\
\hline DS & 38.7398 & 8.6190 & 4.4947 & 0.0000 & 55.6514 & 55.6514 & 21.8281 & 55.6514 \\
\hline TSD & -2.4469 & 1.2397 & 1.9737 & 0.0487 & 0.0143 & 0.0143 & -4.8794 & -0.0143 \\
\hline ES & 37.7125 & 4.4497 & 8.2708 & 0.0000 & 46.6593 & 46.6593 & 28.7657 & 46.6593 \\
\hline AS & 7.3606 & 5.9568 & 1.2357 & 0.2168 & 19.0487 & 19.0487 & -4.3274 & 19.0487 \\
\hline TSA & 2.1076 & 0.6229 & 3.3834 & 0.0007 & 3.3298 & 3.3298 & 0.8853 & 3.3298 \\
\hline \multirow[t]{2}{*}{ Where } & \multicolumn{3}{|c|}{$\mathrm{Ds}=$ Demutualisation Status } & \multicolumn{5}{|c|}{ TSD $=$ Time Since Demutualisation } \\
\hline & \multicolumn{3}{|c|}{$\mathrm{ES}=$ Economics Status } & \multicolumn{5}{|c|}{ AS $=$ Automation Status } \\
\hline \multicolumn{4}{|c|}{ TSA $=$ Time Since Automation } & & & & & \\
\hline
\end{tabular}

Table 2: Market capitalization regression output.

\begin{tabular}{|c|c|c|c|c|c|c|c|c|}
\hline \multicolumn{9}{|c|}{ Regression Statistics } \\
\hline Multiple R & 0.54 & & & & & & & \\
\hline R Square & 0.29 & & & & & & & \\
\hline $\begin{array}{l}\text { Adjusted R } \\
\text { Square }\end{array}$ & 0.28 & & & & & & & \\
\hline Standard Error & 55.30 & & & & & & & \\
\hline Observations & 1100 & & & & & & & \\
\hline \multicolumn{9}{|l|}{ ANOVA } \\
\hline & $d f$ & SS & MS & $F$ & Significance $F$ & & & \\
\hline Regression & 6 & $1,358,165$ & 226,361 & 74.01 & 0.00 & & & \\
\hline Residual & 1093 & $3,342,977$ & 3059 & & & & & \\
\hline \multirow[t]{2}{*}{ Total } & 1099 & $4,701,142$ & & & & & & \\
\hline & Coefficients & Standard Error & t stat & P-value & Lower 95\% & Upper 95\% & Lower $95.0 \%$ & Upper $945.0 \%$ \\
\hline Intercept & 1.0545 & 2.8144 & 0.3747 & 0.7080 & -4.4676 & 6.5767 & 4.4676 & 6.5767 \\
\hline AGE & 0.0259 & 0.0238 & 1.0907 & 0.2757 & 0.0207 & 0.0725 & 0.0207 & 0.0725 \\
\hline DS & 29.1151 & 7.5434 & 38597 & 0.0001 & 14.3139 & 43.9163 & 14.3139 & 43.9163 \\
\hline TSD & 1.5721 & 1.0850 & 1.4489 & 0.1477 & 0.5569 & 3.7010 & 0.5569 & 3.7010 \\
\hline ES & 26.7165 & 3.9907 & 6.6947 & 0.0000 & 18.8862 & 34.5468 & 18.8862 & 34.5468 \\
\hline AS & 9.1067 & 5.2134 & 1.7468 & 0.0810 & 19.3361 & 1.1228 & 19.3361 & 1.1228 \\
\hline TSA & 2.9060 & 0.5452 & 5.3302 & 0.0000 & 1.8362 & 3.9757 & 1.8362 & 3.9757 \\
\hline
\end{tabular}

Table 3: Value of stocks traded as \% of GDP regression output.

The results show that while demutualization is associated with more exchange listings, automation has an almost equally significant negative effect on listings. However, evidence shows that exchanges that have been demutualized for longer tend to have fewer listings compared to newly demutualized exchanges, suggesting potential effects of competition and merger activity post-demutualization. On the contrary, automation tends to yield positive results with time, potentially due to learning curve effects.

\section{Interpretation of findings and implications}

By combining all the regression outputs above, it can be seen that demutualization and economic status of a country have the greatest positive impact on market capitalization, value of stocks traded and stock exchange listings. This implies that demutualized exchanges in developed economies experience the best performance after controlling for age and trading technology. Age has a significant positive effect on listings but a significant negative effect on market capitalization. Therefore, while older exchanges tend to have more participating companies, their relative economic significance tends to be lower, ostensibly due to the sheer size of their economies. There is insufficient evidence at the $5 \%$ level of significance to suggest that simply automating an exchange improves its performance. However, there is evidence to suggest that over time, automation is associated with better stock exchange performance, ceteris paribus.

The negative effect of automation on values of stocks traded may suggest that automation tends to improve the price discovery process 


\begin{tabular}{|c|c|c|c|c|c|c|c|c|}
\hline \multicolumn{2}{|c|}{ Regression Statistics } & & & & & & & \\
\hline Multiple R & 0.54 & & & & & & & \\
\hline R Square & 0.29 & & & & & & & \\
\hline $\begin{array}{l}\text { Adjusted R } \\
\text { Square }\end{array}$ & 0.28 & & & & & & & \\
\hline Standard Error & 55.30 & & & & & & & \\
\hline Observations & 1100 & & & & & & & \\
\hline \multicolumn{9}{|l|}{ ANOVA } \\
\hline & $d f$ & SS & $M S$ & $F$ & Significance $F$ & & & \\
\hline Regression & 6 & 173,775829 & $28,962,638$ & 33.89 & 0.00 & & & \\
\hline Residual & 1093 & $934,198,118$ & 854,710 & & & & & \\
\hline \multirow[t]{2}{*}{ Total } & 1099 & $1,107,973,948$ & & & & & & \\
\hline & Coefficients & Standard Error & t-stat & $P$-value & Lower 95\% & Upper 95\% & Lower $95.0 \%$ & Upper $945.0 \%$ \\
\hline Intercept & 18.3242 & 47.0470 & 0.3895 & 0.6970 & -73.9885 & 110.6369 & -73.9885 & 110.6369 \\
\hline AGE & 3.0072 & 0.3972 & 7.5714 & 0.0000 & 2.2279 & 3.7865 & 2.2279 & 3.7865 \\
\hline DS & 306.8532 & 126.1015 & 2.4334 & 0.0151 & 59.4248 & 554.2817 & 59.4248 & 554.2817 \\
\hline TSD & -64.0231 & 18.1382 & -3.5297 & 0.0004 & 99.6127 & -28.4336 & -99.6127 & -28.4336 \\
\hline ES & 371.7618 & 66.7115 & 5.5727 & 0.0000 & 240.8646 & 502.6589 & 240.8646 & 502.6589 \\
\hline AS & -336.5572 & 87.1520 & -3.8617 & 0.0001 & -507.5613 & -165.5531 & -507.5613 & -165.5531 \\
\hline TSA & 36.2755 & 9.1137 & 3.9803 & 0.00001 & 18.3931 & 54.1579 & 18.3931 & 54.1579 \\
\hline
\end{tabular}

Table 4: Listings regression output.

on stock markets and limit arbitrage activities.However, automation may reduce trading activity in the short run by limiting scope for interaction between buyers and sellers to negotiate price, which results in fewer trades. Thus, automation may have a positive impact on stock exchange performance only in the long run.However, given the significant negative impact on listings and volumes traded, another more inquisitive interpretation could suggest that demutualization and automation may not deliver the much needed revival on the ZSE if implemented simultaneously.

\section{Conclusion}

In line with the findings of Mendiola and O'Hara [8], the study concludes that demutualization is value enhancing. Value enhancement can be acknowledged and tested in many ways. Nevertheless, the study, just like Krishnamurti et al. (2003), focused on mutual and demutualized stock exchanges and found that demutualization has a positive impact on market capitalization, stock market liquidity, and number of listed entities. Overally, the study revealed that demutualization enhances stock market performance as suggested by Aggarwal [1] Otchere [17] Otchere and Abou- Zied [23] with regard to automation,however, the study concludes that it is only over a longer period of time that automation can have a positive impact on stock exchange performance. This is generally in contrast with most literature which shows that automation improves stock market performance regardless of time.

In view of the foregoing empirical evidence, it is important to critically reexamine the joint issues of demutualization and automation within the Zimbabwean context to avoid an anticlimax. The negative impact of automation on volumes and listings may mean less trading income for brokers and investment banks, as well as other stakeholders, which may explain some of the stakeholder resistance to date. It is important to take these stakeholder concerns seriously to ensure efficient design of incentive structures in the new dispensation.

Simultaneous implementation is a notable departure from the norm, yet there is need for further consultation with experts from other experienced markets to avoid parochial benchmarking with very recent cases such as Kenya. It is also clear that economic circumstances exert an important influence on the value-creation processes accompanying the demutualization. Further research is recommended to focus on the economics of demutualization in cases where the process is adopted under strained economic conditions. If demutualization is adopted for purposes of merely improving the operational and governance proficiency of an exchange, certainly is associated with different mechanics from one that is adopted as an economic survival strategy.

\section{References}

1. Aggarwal R (2002) Demutualization and Corporate Governance of Stock Exchanges. Journal of Applied Corporate Finance 18: 106-113.

2. Schmiedel H (2002) Total factor productivity growth in European stock exchanges: a non-parametric frontier approach. Bank of Finland discussion paper 11.

3. World Federation of Exchanges (WFE) (2005) Annual Report and Statistics 2005.

4. Mlambo C, Biekpe N (2007) The efficient market hypothesis: Evidence from ten African stock markets. Investment Analysts Journal 66.

5. Lee R (2002) The future of securities exchanges.Brookings, Wharton Papers on Financial Services 1-33.

6. Kondgen J (1998) Ownership and Corporate Governance of Stock Exchanges Journal of Institutional and Theoretical Economics 154: 224-251.

7. Shleifer A, Vishny R (1997) Large shareholders and corporate control. Journal of Political Economy 95: 461-488.

8. Mendiola, A, O'Hara M (2003) Taking Stock in Stock Markets: The Changing Governance of Exchanges. Working Paper, Cornell University.

9. Aggarwal R, Dahiya S (2005) Demutualization and Public Offering of Financial Exchange. Journal of Applied Corporate Finance 18: 96-106.

10. Hart O, Moore J (1996) The governance of exchanges: member's cooperatives versus outside ownership. Oxford Economic Policy Journal 12: 53-69.

11. Cybo-Ottone A, Di Noia C, Murgia M (2000) Recent Development in the Structure of Securities Markets Brookings-Wharton Papers on Financial Services.

12. Steil B (2002) Changes in the Ownership and Governance of Securities Exchanges: Causes and Consequences. The Wharton School Financial Institutions Center, Brookings-Wharton Papers on Financial Services 1-31.

13. Di Noia C (1998) Customer controlled firms: the case of stock exchanges Working Paper, Wharton School R.L. White Center for financial research.

14. Pirrong C (2000) A Theory of Financial Exchange Organization. Journal of Law and Economics 43: 437-471

15. Domowitz I, Steil B (1999) Automation, trading costs and the structure of the 
Citation: Nyangara D, Musikavanhu TP (2014) An Empirical Analysis of the Impact of Demutualization on Stock Exchange Performance: Lessons for Zimbabwe. Int J Econ Manag Sci 3: 161. doi: 10.4172/2162-6359.1000161

securities trading industry. Brookings-Wharton Papers on Financial Services 33-81

16. Hazarika S (2005) Governance Change in Stock Exchanges. Working Paper University of North Carolina Chapel: Hill.

17. Otchere I (2008) Stock exchange self-listing and value effects. Journal of Corporate Finance 926-953.

18. Morsy A, Rwegasira K (2010) An Empirical Investigation of the Demutualization Impact on Market Performance Stock Exchanges. International Research Journal of Finance and Economics 1: 38-58.

19. IOSCO Technical Committee (2001) Issues Paper on Exchange Demutualisation.

20. Shahid A (2002) Small Stock Markets in a Globalized World. Project Syndicate: An Association of Newspapers around the World.

21. Ramos SB (2006) Why do stock exchanges demutualize and go public?,Instituto Superior de Ciências do Trabalho e da Empresa (ISCTE): School of Business.

22. Krishnamurti C, Sequeira JM, Fangjian F (2003) Stock Exchange Governance and Market Quality. Journal of Banking and Finance, 27: 1859-1878.

23. Otchere I, Abou-Zied K (2007) Stock exchange demutualization, self-listing and performance: The case of the Australian stock exchange. Journal of Banking \& Finance 32: 512-525

24. Nu Ri J (2011) A Study on Demutualization of Stock Exchanges -Focusing on the Case of Korea Exchange.

25. Lucy J (2004) Market demutualization and privatisation: The Australian experience. International Organization of Securities Commission (IOSCO): Amman 2004 Annual Conference.

26. Oldford E, Otchere I (2011) "Can Commercialization Improve the performance of stock exchanges even without Corporatization. The financial review 46: 67-87.

27. Macey JH, M O'Hara (1999) Globalization, Exchange Governance and the Future of Exchanges. Working Paper, Brookings-Wharton Papers on Financial Services: 1-33.

28. Coffee J (1999) Privatization and Corporate Governance: The Lessons from Securities Market Failure. Journal of Corporation La 1-39.

29. Karmel R (2000) Turning seats into shares: implications of demutualization for the regulation of stock and futures exchanges. Working paper.

30. Jensen MC, Meckling WH (1976) Theory of the firm: Managerial behavior agency costs and ownership structure. Journal of Financial Economics 3: 305

31. Agrawal A, Knoeber C (1996) Firm performance and Mechanisms to Control Agency Problems between Managers and Shareholders. Journal of Financial and Quantitative Analysis 31: 377-397.

32. Burkart M, Gromb D, Panunzi F (1997) Large shareholders, monitoring and the value of the firm. The Quarterly Journal of Economics, 112: 693.

33. Pagano M, Röell A (1998) The choice of stock ownership structure: Agency costs, monitoring and the decision to go public. The Quarterly Journal of Economics 113: 187.
34. Fama EF, Jensen MC (1983) Separation of Ownership and Control. The Journal of Law \& Economics 26: 301-325

35. Kole S, Lehn K (1997) Deregulation, the Evolution of Corporate Governance Structure, and Survival. The American Economic Review 87: 421.

36. Benveniste L, Marcus A,Wilhelm W (1992) What's so special about the specialist? Journal of Financial Economics 32: 61-86.

37. Biais B (1993) Price Formation and Equilibrium Liquidity in Fragmented and Centralized Markets. Journal of Finance $48: 157-185$.

38. Naidu GN, Rozeff MS (1994) Volume, Volatility, Liquidity and Efficiency of the Singapore Stock Exchange Before and After Automation. Pacific-basin Finance Journal $2: 23-42$.

39. Galper J (1999) Three business models for the stock exchange industry, a working paper. International Federation of stock exchanges.

40. Patrick H(1966) Financial development and economic growth in underdeveloped countries. Economic Development and Cultural Change 14: 174-189.

41. Ibrahim HM (1999) Macroeconomic indicators and stock prices in Malaysia: An empirical analysis. Asian Economic Journal 13: 219-231.

42. Charkravarty S (2005) Stock market and macroeconomic behavior in India India: Institute of Economic Growth Delhi.

43. Levine R, Zervos S (1996) Stock Markets, Banks, and Economic Growth American Economic Review 88: 536-558.

44. Benchivenga VR, Smith BD (1991) Financial Intermediation and Endogenous Growth. The Review of Economic studies 58: 195-209.

45. N'zue F (2006) Stock Market Development and Economic Growth: Evidence from Cote D'lvore. Africa Development Review 18: 123-145.

46. Tuncer GC, Alovsat M (1998) Stock markets and economic development Causality tests. Istanbul Technical University.

47. Luintel KB, Khan M (1999) A quantitative reassessment of the finance-growth nexus, Evidence from a multivariate VAR. Journal of Development Economics 60: $381-405$

48. Garcia VF, Liu L (1999) Macroeconomic Determinants of Stock Market. Journal of Applied Economics 2: 29-59.

49. Lucas RE (1988) On the mechanics of economic development. Journal of Monetary Economics 22: 3-42.

50. Stern N (1989) The economics of development: A survey. Economic Journa 99: 597-685.

51. Leonard-Bart on D (1992) Core capabilities and core rigidities: A paradox in managing new product development. Strategic Management Journal 13: 111-125.

52. Hannan MT, Freeman J (1984) Structural inertia and organizational change. American Sociological Review 49: 149-164.

53. Yartey CA (2008) Determinants of Stock Market Development in Emerging Economies: Is South Africa Different? IMF working Paper-WP/08/32 Washington, International Monetary Fund. 